Copyright (c) 2016 SBPjor / Associação Brasileira de Pesquisadores em Jornalismo

\section{POLITICAL ECONOMY OF POPULAR JOURNALISM IN COMPARATIVE PERSPECTIVE:}

an analysis on tabloidization in Brazil, India and South Africa'

Viktor Chagas

Universidade Federal Fluminense, Brazil

\begin{abstract}
At the turn of the 1990s to the 2000s, a debate on an alleged "tabloidization" of the European press took academic research on journalism, especially since the works of Esser (1999) and Sparks \& Tulloch (2000), which sought to conceptualize the term. The academic literature since then has dealt with the subject in different settings and contexts around the world (cf. PIONTEK, 2011; MOONEY, 2008; LIMA, 2009). In Brazil, however, there were few efforts in order to deepen the knowledge on tabloid genre. The main purpose of this article is to characterize the phenomenon as it appears in the Brazilian market, comparing the performance of tabloids to what authors like Wasserman (2010), Ogola \& Rodny-Cumede (2014) and Ranganathan \& Rodrigues (2010) have observed in countries like India and South Africa.
\end{abstract}

Keywords: tabloidization; popular journalism; political economy of journalism; BRICS.

\title{
ECONOMIA POLÍTICA DO JORNALISMO POPULAR EM PERSPECTIVA COMPARADA: uma análise sobre a tabloidização no Brasil, na Índia e na África do Sul
}

RESUMO - Na virada da década de 1990 para os anos 2000, uma discussão sobre a "tabloidização" da imprensa europeia tomava a pesquisa acadêmica sobre jornalismo, sobretudo a partir dos trabalhos de Esser (1999) e Sparks \& Tulloch (2000), que buscaram conceituar a expressão. A literatura acadêmica, desde então, tem tratado do tema em diferentes cenários e contextos pelo mundo (cf. PIONTEK, 2011 ; MOONEY, 2008; LIMA, 2009). No Brasil, porém, foram poucos os esforços de se tentar compreender a adesão ao gênero tabloide. A proposta deste artigo é caracterizar o fenômeno tal como ele se apresenta no cenário econômico brasileiro, comparando seu desempenho ao que autores como Wasserman (2010), Ogola \& Rodny-Gumede (2014) e Ranganathan \& Rodrigues (2010) têm observado em países como Índia e África do Sul.

Palavras-chaves: tabloidização; jornalismo popular; economia política do jornalismo; BRICS 


\section{LA ECONOMÍA POLÍTICA DEL PERIODISMO POPULAR EN PERSPECTIVA COMPARADA: un análisis de la tabloidización en Brasil, India y Sudáfrica}

RESUMEN - A la vuelta de la década de 1990 a la década de 2000, un análisis de la "tabloidización" de la prensa europea tomó la investigación académica sobre el periodismo, desde el trabajo de Esser (1999) y Sparks y Tulloch (2000), que tenía por objeto conceptualizar la expresión. La literatura académica desde entonces ha tratado el tema en diferentes escenarios y contextos en todo el mundo (cf. PIONTEK, 2011; MOONEY, 2008; LIMA, 2009). En Brasil, sin embargo, hubo pocos esfuerzos para tratar de entender al género de los tabloides. El propósito de este artículo es caracterizar el fenómeno en el mercado brasileño, comparando su desempeño a lo que autores como Wasserman (2010), Ogola y Rodny-Gumede (2014) y Ranganathan y Rodrigues (2010) tienen observado en países como India y Sudáfrica.

Palabras-claves: tabloidización; periodismo popular; economía política del periodismo; BRICS.

In the turn of 1990s to 2000s, discussion on "tabloidization" of the European and North-American press took research on journalism by assault. Especially from the seminal works of Esser (1999), Sparks (1998) and Sparks \& Tulloch (2000) on, which have delimited conceptual borders of the expression, much was argued on a contamination effect on prestige press by a "tabloid agenda". Because of that, tabloid journalism was generally evoked as an indefectible villain by most of accuracy press advocates. More recently, other researchers, like Wasserman (2010), and Ranganathan \& Rodrigues (2010), more aligned with a South-to-South dialogue perspective, have managed to call attention to the tabloid's role in political economy of journalism, pointing to business models as one key to understand printed press crisis in developed countries. Fact is that countries such as India (Ranganathan \& Rodrigues' field), South Africa (Wasserman's field) and Brazil are highlighted as some exceptions in a scenario of clear economical recession for newspapers all over the world. Differently than the others, Brazil has invested in a distinct economical model, which juxtaposes prestige press and tabloids as allies not competitors, as we have shown before (LATTMAN-WELTMAN \& CHAGAS, 2013; 2014; CHAGAS, 2014). There is nevertheless little or no research on this matter.

This paper, then, aims to (1) make a theoretical investment on the applicability of "tabloid" category and in the process described 
by the "tabloidization" concept in Brazilian landscape; (2) analyze and subsequently deepen the investigation on economical issues related to popular journalism in Brazil, India and South Africa; (3) propose an agenda of research over these subjects which takes into consideration a broader view on the political economy of the media. To present these questions in a consistent manner, we divided this paper in three sections. In the first one, we'll review the literature on "tabloidization" in its different approaches. Then, on the second section, we'll show how this debate has been treated recently by different scholars in their investigations on the political economy of journalism among the BRICS (particularly in Brazil, India and South Africa). At the end, we'll map the space occupied by tabloid journalism in the political economy of journalism in Brazil, proposing issues for further discussions. As we'll see in the following pages, the first generation of studies on tabloid journalism was characterized by an approach that privileges the content dimension, in expectation of understanding the manners whereby the so-called tabloid agenda is able to infect quality news. This interpretation is present in Sparks (2000), in Gripsrud (2000), and, in a certain way, is updated in Chagas (2015). The second generation of studies, however, compromises itself in understanding tabloids through their social role, as agents capable of building collective identities. This is the case of Fiske (2011), Glynn (2000), Wasserman (2010) and Nina (2012), to name a few. In all these works, however, lies dormant a comprehension of tabloid journalism as a product in circulation, or a mass communication medium. This is what puts together such distinct views, including ours. We do not understand the tabloid as a format or a language, simply². Just the opposite: we intend to define it from a wider perspective. From the political economy of press theoretical background, the tabloid stands for the convergence point between supply and demand of information in the contemporary scenario.

While most of the national and international literature on journalism has been concerned with the so-called world crisis of the press (SANT'ANNA, 2008; MEYER, 2007), it's still difficult to find scholar research on issues related to the effects of this crisis as they're experienced by different national contexts, and even more rare to find an alternative model to this one, that takes into consideration local aspects, in contrast to the well-known Western paradigm of press analysis.

Hallin \& Mancini (2004 and again in 2012) already had the opportunity to suggest that scholars focus with greater enthusiasm in comparative analyses. Nevertheless, besides having collected cases from 
Russia to Brazil, from Eastern Europe to Africa, both the two political scientists and their collaborators overemphasized their efforts on the incidence of political parallelism and in the media professionalization process through history. The relation between public and private investments presented by the role of the State's and the market structure's axes is considered on a basic level, just when Hallin \& Mancini (2004) work with variables such as distinction level over the prestige press and the tabloid press, the importance of printed press and television stations as sources of political information, and the readerships and circulation rates among newspapers. But nor the authors neither their collaborators propose an approach that help us explain why different media systems experience different effects when facing the crisis.

As a result, we still need a comparative model, focused on understanding this landscape and capable of answering which vectors of the crisis - such as the technological changes, the governmental regulation or the changes in media economical ownership - are responsible for triggering this or that issue. Our analysis focuses these questions, calling attention to the fact that theoretical models adopted as explanation to the development of mass circulation printed press, such as the Penny Press, can and must be relativized, in light of local social-economical-cultural contexts' own characteristics. If we, in Brazil, usually speak in a "popular press", and not in a "tabloid press", this is very likely due to the media ownership conditions and the financial investments (mostly public investments) over the media. The way that popular titles are intertwined with mainstream media groups, for instance, is an important variable to determine these effects. On the other hand, although not our concern at the present moment, it's also important to consider the causal factors of this scenario. So, the recent professionalization of the journalism, in consonance to the democratic reopening of the country, help us to explain the emphasis given by some authors on the political plurality-centered debate and the debate on the democratic regulation over the media (AZEVEDO, 2006). It seems that the same perspective has been adopted by scholars from distant national contexts, such as Wasserman (2010), in South Africa - who describes the post-Apartheid regime and the role assumed by the popular press as anchor of a recently built collective identity, also discussing how the media ownership changes affected the local reality. We, by the other hand, more aligned with the recent Indian literature approach (RANGANATHAN \& RODRIGUES, 2010; NINAN, 2012), are not concerned in discussing the production 
sphere of the political news but in investigating the access of the common citizen to political information.

The study of Esser opened doors to Sparks \& Tulloch's anthology. In the introductory chapter of the book, Sparks develops his own theoretical-methodological model to evaluate tabloidization phenomenon. Following his scale (2000, pp. 12-15), it's possible to recognize distinct levels of tabloidization, arranged in a Cartesian graphic which considers the horizontal axis going from the news coverage on politics, economics and society issues to the news coverage on scandals, sports and entertainment issues, and the vertical axis going from the concentration on public life to the concentration on private life matters. The result is the following (image 1.1).

In the scale provided by Sparks it's also presented clearly the distinction made by Gripsrud (2000), later in the same volume, whereby not all popular journalism must be faced as tabloid. In Gripsrud's model, easily understood as a concentric pattern, tabloid journalism would figure as an intermediary pattern between popular journalism and trash journalism, an even more radical trend in what concerns to sensationalism and to the misrepresentation of public affairs.

\section{Image 1.1. Sparks' tipology}

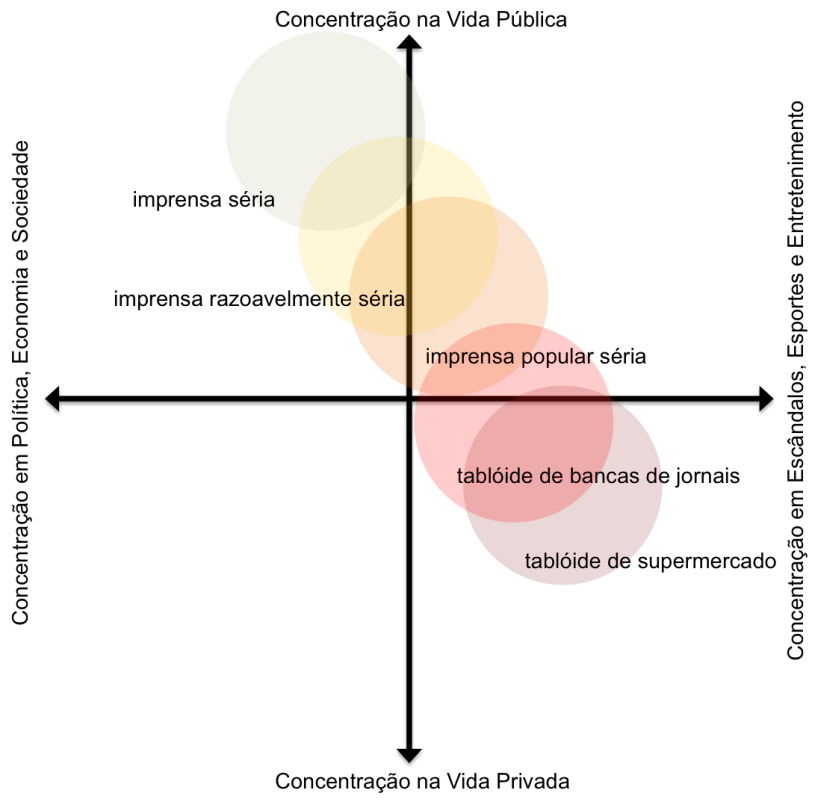

Source: Art from the author over Sparks' tipology (2000). 
Gripsrud (2000) is one among other voices to highlight the shades of popular journalism, noting that the antithetical model commonly adopted by researchers did not summarize all the complexity of the phenomenon. For him, it was possible to find more intermediary levels between the serious press and the yellow press, including the one he would call the "quality popular" (image 1.2).

Tabloids, yet, do not perfectly fit in none of the three vertices of Schudson's triangular model (SCHUDSON, 1999), which points to a market media, an advocacy media and a trustee media. The first one would be funded by an economic model based on advertising and direct sales to audiences. According to Schudson, this model overcame in American press (but not in all over the world) the one that bets on partisan organizations as financial supporters for the media. The third one would introduce an independent journalistic model, anchored in a subjective approach, related to civil associations and interested groups. At the end, what we notice is that, while they are clearly targeted to commercial purposes, tabloids do not have any restrictions to the other two models, and they seem to explore to the limit the levels of journalistic subjectivity in their news pieces.

\title{
Image 1.2. Gripsrud's tipology
}

\author{
jornalismo popular \\ jornalismo tabloide \\ jornalismo trash
}

Source: Art from the author over Gripsrud's tipology (2000). 
Later, scholars such as Langer (2003) used an expanded notion of the concept to comment the upsurge of sensationalism in television; others, such as Glynn (2000), in order to enlarge the definition, worked with the concept of "tabloid culture".

What becomes evident in the studies of this first generation, at the end of the 1990s, is that, either in Europe, or in the United States, the so-called "tabloidization" is routinely seen as a menace or a revolutionary condition to the masses. Scholars like Esser (1999) himself argued that the phenomenon could be more precisely understood if we recognize two different perspectives, a micro and a macro ones, each of them with its own emphasis and alignments. From one side, we would have authors like Frank Esser, Colin Sparks and Ulrike Klein. From the other, Elizabeth Bird, John Fiske and Kevin Glynn.

The first group, for instance, would pursue a journalism of public interest, and would not hesitate in classifying tabloids as a huge sensacionalist menace to prestige press. It's not difficult to assume this point of view when we are confronted with the effects of the hard competition imposed on quality papers by popular titles. This landscape, however, as we'll see, would favor a reading typically centered in Western European and North-American cases, largely negative, due to the decline of the mainstream media in these countries/regions. In defense of the ideal of quality journalism, such authors would be faced by other theorists as members of an elitist current.

By contrast, Bird and Fiske, among others, would emphasize the irreverent and subversive style of tabloids, same one that would permit an interpretation of popular journalism as a challenger of the so-called "power bloc". A bit more moderate than her colleague, Bird (2000, p. 214) would admit that Sparks had a convincing point in hand when he affirmed that there is hardly any evidence that readers take for themselves the ironical point-of-view that Fiske suggests, and that they, in reality, end up showing a conservative view of facts. Anyway, she said, there is still a limited quantity of researchs on these audiences related to the tabloidization process.

Struggle between "populist" and "elitist" visions over the relation between journalism, culture and society, summarized scholar agenda when discussing the phenomenon of "tabloidization". Since then, literature have been exploring episodically the question through different lenses and on different contexts (cf. PIONTEK, 2011 on Poland; MOONEY, 2008 on Irish press; HARRIS, 2006 on modern North-American press; LIMA, 2009 on the relationship 
between tabloids and online journalism, and many others). Mostly, studies on tabloidization, which inherit the tradition of the debates that began in the 1990s, suggest a contrast between tabloid and prestige press fatally delimited not by its economical model but by its content. Tabloids, in this sense, are always contaminants, for good or evil, regarding the traditional printed press, they never share with it the same values.

While most of the literature have concentrated in advising on the crisis and eventually associating it to a process of tabloidization, it's still difficult to find an academic contribution that seeks to understand the effects of this crisis in different regions of the world. As a result, the analyses generally reproduce the Western classic model (read the North-American and European model) that sometimes demonizes, sometimes sanctifies tabloidization, and sees the crisis by the lenses of mainstream media conglomerates. This is due to the fact that both interpretive trends, the one that "supports" and the one that "fights" tabloid experiences, are based in content analyses of the titles, not in political economical approaches.

By contrast, works lead by some developing countries suggest that an analysis of informational market behavior may enlighten questions such as the positive trend of growth in printed press recent performance, especially in the segment of newspapers, in regions like those. In such cases, an economical perspective might help to show, with more precision, the play of forces between mainstream media and other contenders.

\section{Menace or revolution? The first generation of studies on "tabloidization" phenomenon in the 1990s}

Studies on the "tabloidization" phenomenon flourished about twenty years ago in Europe and United States, and, since then, have been sparsely revisited. This movement seems to show that the main concerns in studying the phenomenon in Western Europe and United States were fairly exhausted in last decades. Nevertheless, that literature from the 1990s is largely the one still adopted by scholars researching this subject. Among the main works, generally taken as starting point for these new analyses, it's easy to find references to Esser (1999), Sparks (1998) and Sparks \& Tulloch (2000). 
In this chronology, one of the first volumes to address this subject was edited by Colin Sparks (1998), as a special dossier in the Slovenian journal Javnost - The Public. With texts from Ian Connell, Elizabeth S. Bird, Kaori Hayashi, Agnes Gulyas, Ulrike Klein, Dick Rooney, Mira MacDonald and Sparks himself, the issue pioneered in proposing a supranational and interdisciplinary approach, reuniting works from United States, Germany, Japan, United Kingdom and Hungary. Some of them, together with other articles, were further published in the anthology that Sparks signed with professor John Tullochs (2000), entitled Tabloid Tales. Before that, Sparks have edited with Peter Dalhgreen (1992) another book on journalism and popular culture in the wake of works from Kurtz (1993) and Fiske (2011).

In Germany, Frank Esser (1999) did a comparative analysis between German and British press, discussing the development of printed press in both countries, and how, due to "tabloidization", would journalists' perception over their professional ethos changed. Presenting "tabloidization" as a process in which quality papers were contaminated by a "tabloid agenda", that minimizes political issues in favor of a sensational news coverage, filled with scandals, Esser would argue that, for better understanding this process, it would be fruitful to investigate prestige press, not the tabloid press, since it was there that we could find the elements of such crisis. Esser distinguishes between the tabloid format and the tabloid genre ${ }^{3}$, with which he is concerned, and also distinguishes the European tabloid from the American supermarket tabloid. This effort results in a framework according to which "tabloidization" was a process that takes place in time, and implies in a contamination of "serious" media by the style of popular journalism. In Esser's perspective, tabloidization was a movement in which mainstream media was tabloidized by a competitive run for popularity. Concurrence, economical and legal factors (the right for privacy, for instance) were among the main characteristics of this landscape. But, Esser (1999, pp. 293-294) argued, this process wouldn't occur in an uniform manner all over the countries, and there resides the virtues of a comparative study with multidimensional approaches, specially considering that "tabloidization" is still a "vague" concept (ESSER, op. cit.). 


\section{The South-South Axis. Second generation of studies on "tabloidization" in developing countries}

George Brock (2013, p. 142) warily warns that, before we announce that the end of the press is near, due to the crisis we are experiencing, we have first to consider the economical differences among distinct regions. "Over five years to 2012," he says, "newspaper circulations in Asia have grown by 16 per cent, while those in Western Europe and North America have fallen by 17 per cent." And he adds,

Circulations have risen in India, Brazil and China. In India, literacy and purchasing power (newspaper are very cheap) are on the increase. In China, the nervous authorities have been conducting cautious experiments in allowing new publications not under direct state control (id., ibid.).

To these countries we could also add South Africa, which have been facing the adverse scenario betting in the popularization of newspapers. What these countries have in common is the bet in a product portfolio for a mass audience. Tabloids, then, clearly do not present themselves as a menace to traditional journalistic model but its ensuring continuity. At least through an economical point of view, the crisis faced by mainstream media contributes to a great change in expectations. That is the perspective of a new generation of studies on the tabloidization issue.

Authors like Herman Wasserman (2010), Maya Ranganathan \& Usha M. Rodrigues (2010), Sevanti Ninan (2012), George Ogola \& Ylva Rodny-Gumede (2014) have been investigating these new settings in political economy of journalism, so to question the assumptions of the frameworks created by the first generation of scholars, lead by Sparks, Esser and others. The position assumed by this second generation before the tabloidization process rises some new questions, as long as factors like literacy rates, the purchasing power of the people (as indicated by Brock above), the end of civil wars or Apartheid regimes, or the advancing in the popularization of new ICTs (among them the Internet), in addition to the adoption of marketing strategies increasingly more "aggressive" toward the readers, have been contributing to invert the downward curve of consumption of printed press products in developing countries.

Ninan (2012, p. 15), for instance, focusing in Indian case, proposes that Indian newspapers, formerly promoters of national- 
republicanism, now foster the cause of material changes. The sample of National Reading Survey (NRS) in 2005 pointed a total of 200 million readers for newspapers and magazines, against 131 million in 1999. Today there are 98 million people from rural areas of the country, and the average of readers per copy is also declining, from 22 for each copy sold in 1997 to 8.4 in 2006, in the province of Uttaranchal. This means there are more people consuming the paper. The Audit Bureau of Circulation (ABC) also released a report in 2006 that pointed that at least 15 newspapers in hindi and other 11 in English had circulation rates exceeding 100 thousands copies. In the last years, a select group of two of three Indian newspapers have been alternating positions in the largest print run of the planet. The Times of India, the largest vehicle of English language, prints more than 4 million copies a day. The popular Dainik Jagran is not far behind, with 2.8 million copies per day and a range of 17 million readers (SOOD, 2009; AULETA, 2012). The business model of these titles draws massively in advertising revenue, reaching between 66 per cent (Jagran) and more than 90 per cent (Times) of their total revenue with advertising. With this investment, papers like the Jagran can circulate with prices beneath the Rs. 10 (ten Indian rupees) in weekdays and Rs. 4 (corresponding to less than US\$0.07) on Sundays. This landscape became even more attractive to the magazine's market since 2002, when the Indian government expanded the limit to direct foreign investment in print media, bringing to the country national franchises of magazines like Vogue, Marie Claire and others (RODRIGUES, 2010, p. 55).

Another important question, reminds Ninan (2012), is the expressive amount of local dialects that cut the country out, making it difficult to establish a direct communication at country level. Besides Hindi and English, languages such as Telugu and Punjabi are largely adopted by different groups. This condition led the Indian government not only to adopt a system of certain permissiveness in broadcasting channels concessions, but also determined intense regionalization for print titles. Thus, a group of regional titles, which further became medium-sized media conglomerates started to act as local political voices, controlling television channels and online content web portals.

Rodrigues (2010, p. 54) cites the results of other scholar, Vipul Mudgal, to remind that the distribution companies of the major newspapers developed expertise on account of their past as distributors of beverages in India. As the business consisted in a 
complex logistic of quick delivery, such distributors revolutionized the extension of the printed titles circulation, attracting more advertisers and reverting a hitherto negative frame. According to Indiantelevision.com, in a 2009 research, 48 per cent of the media advertising revenue in the country is invested in print media, while not more than 37 per cent goes to television. For comparison purposes, in Brazil, television receives 66 per cent of the total amount of investments, while newspapers receive just 10 per cent, according to 2013 data from project Inter-Meios.

Low prices, advertising-based business models, wide and open regional competition, fostered especially by newspapers of simple language and popular appeal. These characteristics help to explain, at least partially, the success of Indian case.

Unlike what occurs in India, South Africa (and also in Kenya, according to the authors), the promising landscape for tabloids is due to the legacy of media ownership concentration in oligopolies such as those described by Ogola \& Rodny-Gumede (2014, pp. 230-231).

\footnotetext{
Under Apartheid South Africa, newspapers were essentially controlled by four companies, and little has changed. Today, two out of the four companies dominate South Africa's newspaper scene [...], which together control approximately two-thirds of the market [...].

The concentration in ownership post-Apartheid has translated into healthy profits for the owners, but journalism has been suffering.
}

In a nutshell, similarly to what happened in Brazil, the change in political system did not prevent that the media monopoly would continue established. Nevertheless, Wasserman's diagnosis (2010, p. 86) on South Africa, as much as Ninan's (2012) on India, is that tabloids can indeed perform an important political role in fostering the development of a new and alternative public sphere in the country, resisting to the exclusion of determined groups from the mediated discourse, and providing to these readers an open participatory path to formal politics.

The first tabloids in South Africa date approximately from 1930s and 1940s (WASSERMAN, 2010, p. 48), but the definitive impulse for the genre is recent. Together, technological, social and economical changes, in addition with changes in ownership of media and other political issues from the end of Apartheid, create the basis for the crisis in mainstream media in the country. According to Wasserman 
(2010, p. 20), apart from the tabloids themselves, traditional SouthAfrican newspapers have been suffering great losses in circulations in recent years. But, although at first sight, the researcher seems to align with the tabloid critics, his argumentation sustains that some scholars settled down in the classic distinction between the traditional and the alternative media as irreconcilable poles, without noticing that tabloid press itself constitutes a third wave that stresses this dichotomy and assumes characteristics from both extremes. The tabloid, he says, presents at the same time a lucrative perspective of the press, which opposes to alternative media, and recognizes itself eminently as a popular product, in a critic to mainstream elite media. Thereto, popular newspapers work as an "emergent public space in which citizenship is constantly rehearsed and negotiated" (WASSERMAN, 2010, p. 47). Prognostics require confirmation, but Wasserman's research perspective is clear in betting on a critical approach to political economy.

Like other authors from this second generation of tabloid studies, Wasserman advocates an analytical and conciliatory perspective between former micro and macro biases. Such authors bet on comparative studies, as Esser (1999) suggested, but discard an aprioristic perception of the effects of tabloidization either as a positive or a negative process. Moreover, and as an evident result of a multi-polarization economical setting, academic debate has intensified itself in developing countries, creating an interesting dialogue between such realities and particularities.

Instead of viewing local media as particular examples of a globally dominant (...) blueprint, a translocal approach would encourage comparisons between different 'local' media, or South-South studies, such as comparisons between tabloids in different parts of the developing world or in different African countries

(WASSERMAN, 2010, p. 55).

In this sense, studies on popular journalism in Brazil need a more investigative impetus. Most of the studies presented by Brazilian scholars in Political Economy of the Press field are divided in either (a) a genealogy of the broadcasting media, expecting to understand the "national integration" model inherited from the military dictatorship and its effects in the concentration of financial investments (LEAL FILHO, 2008), or (b) an analysis on the emancipatory and counter-hegemonical potential of the community 
media (CABRAL, 2008; CABRAL, 2008), anchoring its theoretical discussion on reviews of Gramsci's and Frankfurt School's tradition as much as on a discourse analysis with a Foucaultian approach. There are, however, clear gaps, as shown below, in the understanding of the economic organization of these media conglomerates and the political space they now occupy.

\section{Brazilian market of popular newspapers}

Brazil is prodigal in incorporating alternative forms of journalism that mix humor and subjectivity. Since at least the mid1950s, one can recognize the emergence of a new popular genre in the country, permeated by the vector of political parallelism in newspapers like O Dia (The Day), Diário de Notícias (Daily News) and O Povo (The People). Before that, one can argue, illustrated magazines in $19^{\text {th }}$ Century already merged tabloid journalism and partisan pamphlets. But mostly since the process of re-democratization and with the rearrangement of some media groups in the 1980s and 1990s, tabloids reached new audiences in Brazilian metropolitan areas. Sometimes even printed in typical mainstream broadsheet, other using an intermediary Berliner, and just in a few cases really adopting the tabloid format, these titles emerged as largely accessible papers, and in recent years have obtained good direct sale rates. Some of the titles are shown among the lists of top circulations of the country in last decade.

In Brazil, else than in other countries, borders between tabloid and mainstream journalism have an economical component that defies our immediate comprehension. As popular newspapers are sponsored by the same media conglomerates that owns mainstream titles, the landscape presents an extravagant situation where competition is substituted by complementarity.

Actually, in South Africa, Wasserman (2010, pp. 78-9) describes something similar. In his words, however, tabloids are levered on by other products of the same media group, as they have difficulties to cover the costs due to their low final prices.

The debate about tabloids and mainstream media should also contain a critical political-economic focus. All South African tabloids belong to commercial conglomerates, so it could be expected that profitability would be higher on their publishers' agenda than increased public deliberation. The support of 
conglomerates for tabloids is also important when drawing conclusions on the basis of the high popularity of tabloids. The fact that tabloids can sell (...) at a cheap price because they are cross-subsidized by other products in the same media groups should also be factored in when trying to account for tabloids' popularity. Readers may buy tabloids partly because they are cheap, and not only because they provide desired content. Glib and overly easy inferences between content and audience preference should therefore be avoided.

Unlike what occurs in other countries, in Brazil, tabloids supply the market with a supplementary solution, which allies the ability of an advertising uptake and a subscription revenue generated from major newspapers with the absolute success of direct sales revenue from popular titles ${ }^{4}$. Thus, as we already noticed (cf. CHAGAS, 2013; LATTMAN-WELTMAN \& CHAGAS, 2013; LATTMAN-WELTMAN \& CHAGAS, 2014), popular papers have been serving the strategy of the conglomerates that sustain them in diversifying their product portfolio, composing media binomials or trinomials together with other quality papers, so both can reach economical sustainability counting on audience diversity. If it is true that revenues from popular newspapers are still far from the prestige press rates, such strategy may have had contributed to widening the public, considering the recent trend of major newspapers to turn themselves back to elite specific niches. So, the "gentlehood" titles are summed with ones whose brand is not yet so consistent but that hold a broader audience, and then these media groups not only can penetrate new market layers in what we previously called a public discourse market (LATTMAN-WELTMAN \& CHAGAS, 2013), but also present themselves more attractively to the investors. Envisioning this potential, groups like Infoglobo and O Dia offered even promotional prices to combined/cross advertising ${ }^{5}$. And thus the investor preserves assets as credibility and security of his investments in a solid brand as well as expands the scope of advertising to popular classes.

Furthermore, such strategy points to a distinct landscape from that observed by other authors in their respective contexts, and for this reason it presents new challenges and possibilities. One of these challenges is the occurrence of the phenomenon that we previously addressed as "friendly fire" (CHACAS, 2013), that is, a competition among titles of supplementary consumption profile, owned by the same company or group, as it seems to be the case of newspapers O Dia and Meia Hora (Half-An-Hour) in Rio de Janeiro state, in which the first one has suffered several losses in circulation 
after the release of the last in the market.

Thus, at least in Brazil, Penny Press model is widely ineffective to explain the political economy of printed newspapers - since the concentration of investments over prestige titles undermines the sustainable existence of independent tabloids (independent, in that case, from media conglomerates). This, however, does not diminish the political capital of such popular papers before the prestige press, on the contrary: according to our perspective, the tabloids indeed are the responsible for enlarging the penetration of these media groups.

As far as we can deduce, though, Brazilian "tabloidization" follows an alternative path in relation to other parts of the world. Concerning this issue, Belisário (2014, p. 74) adds that "these organizations [the media conglomerates], by marketing reasons, have looked for - even in their traditional versions - an approximation with the news-values of interest of this [popular] social stratum." Hence, the play of forces between actors that in other regions of the world are treated like competitors, gains new contours in Brazil. Notwithstanding, predicting what this landscape holds is no task for us.

*This papers was translated by the author

\section{REFERENCES}

AULETTA, Ken. Citizens Jain: why India's newspaper industry is thriving. The New Yorker. New York, October $8^{\text {th }} 2012$. Available on: <http:// www.newyorker.com/magazine/2012/10/08/citizens-jain>. Last access: March $13^{\text {th }} 2016$.

AZEVEDO, Fernando. Mídia e democracia no Brasil: relações entre o sistema de mídia e o sistema político. Opinião Pública, Campinas (SP), v. 12, n. 1, pp. 88-113, 2006.

BARBOSA, Marialva; ENNE, Ana L. S. O jornalismo popular, a construção narrativa e o fluxo do sensacional. Eco-Pós, v. 8, n. 2, pp. 67-87, 2005.

BELISÁRIO, Kátia Maria. De Chicago a Contagem: páginas do cotidiano no popular mais lido no Brasil. 2014. Thesis (PhD in Communication) - Faculdade de Comunicação Social, Universidade de Brasília, Brasília, 2014.

BIRD, S. Elizabeth. Audience demands in a murderous market: tabloidization in U.S. television news. In SPARKS, Colin; TULLOCH, John. Tabloid tales. New York: Rowman \& Littlefield, 2000, pp. 213-228. 
BROCK, George. Out of print: newspapers, journalism and the business of news in the digital age. London: KoganPage, 2013.

CABRAL, Adilson. Economia política da comunicação no Brasil: terreno fértil para análises maduras. In: BRITTOS, Valério C.; CABRAL, Adilson. Economia Política da Comunicação: interfaces brasileiras. Rio de Janeiro: e-papers, 2008, pp. 76-88.

CABRAL, Eula D. T. A grande mídia diante do local e do comunitário. In: BRITTOS, Valério C.; CABRAL, Adilson. Economia Política da Comunicação: interfaces brasileiras. Rio de Janeiro: e-papers, 2008, 164-178.

CHAGAS, Viktor. Extra! Extra!: os jornaleiros e as bancas de jornais como espaço de disputas pelo controle da distribuição da imprensa e da economia política dos meios. 2013. Thesis (PhD in History, Politics and Cultural Assets) - Cpdoc, Fundação Getulio Vargas, Rio de Janeiro, 2013.

CHAGAS, Viktor. Overlapping webs: an analytical model for use in works on the political economy of printed media. In: IAMCR, 2014, Hyderabad. Annals... Hyderabad (India): IAMCR, 2014.

CHAGAS, Viktor. Leitorado casual, eleitorado habitual: mudanças no ecossistema da informação e suas relações com o comportamento eleitoral das massas. In: Anpocs, 2015, Caxambu. Anais... Caxambu (MG): Anpocs, 2015. Available on:

$<$ http://portal.anpocs.org/portal/index.php?option=com_content\&view= article\&id $=435 \& \mid$ temid $=77>$. Last access: March $13^{\text {th }} 2016$.

ESSER, Frank. 'Tabloidization' of news: a comparative analysis of Anglo-American and German press journalism. European Journal of Communication, v. 14, n. 3, pp. 291-324, 1999.

FISKE, John. Understanding popular culture. New York: Routledge, 2011.

GLYNN, Kevin. Tabloid culture. Durham and London: Duke University Press, 2000.

GRIPSRUD, Jostein. Tabloidizaton, popular journalism, and democracy. In: SPARKS, Colin; TULLOCH, John. Tabloid tales. New York Rowman \& Littlefield, 2000, pp. 285-300.

HALLIN, Daniel C.; MANCINI, Paolo. Comparing media systems: three models of media and politics. Cambridge: Cambridge University Press, 2004.

HALLIN, Daniel C.; MANCINI, Paolo. Comparing media systems: beyond the Western World. Cambridge: Cambridge University Press, 2012. 
HARRIS, Nichola Reneé. Tabloidization in the modern American press: a textual analysis and assessment of newspaper and tabloid coverage of the 'Runaway Bride' Case. 2006. Thesis (PhD in Communication) - Department of Communication, Georgia State University, Georgia, 2006.

JOHANSSON, Sofia. Reading tabloids: tabloid newspapers and their readers. Estocolmo: Södertörns högskola, 2007.

KLEIN, Ulrike. Tabloidized political coverage in the German Bild-Zeitung. In: SPARKS, Colin; TULLOCH, John. Tabloid tales. New York: Rowman \& Littlefield, 2000, pp. 177-194.

KURTZ, Howard. Media Circus: the trouble with America's newspapers. New York: Random House, 1993.

LANGER, John. Tabloid television, popular journalism and the other news. London: Routledge, 2003.

LATTMAN-WELTMAN, Fernando; CHAGAS, Viktor. Insegurança, (re) partidarização e "fogo amigo": a economia política dos meios na Era Lula. Compós, 2013 , Salvador. Anais... Salvador: Compós, 2013. Available on: <http://compos.org.br/anais.php>. Last access: March $13^{\text {th }} 2016$.

LATTMAN-WELTMAN, Fernando; CHAGAS, Viktor. Mercados futuros: um modelo analítico para a economia política dos meios impressos. In: Compós, 2014, Belém. Anais... Belém: Compós, 2014. Available on: <http://compos.org.br/anais.php>. Last access: March 13 2016.

LEAL FILHO, Laurindo L. Sociedade e televisão. In: BRITTOS, Valério C.; CABRAL, Adilson. Economia Política da Comunicação: interfaces brasileiras. Rio de Janeiro: e-papers, 2008, pp. 192-200.

LIMA, Anastasia B. Is there a tabloidization of online news? A content analysis of traditional news websites. Gnovis, v. X, n. I, 2009. Available on: <http://www.gnovisjournal.org/2009/12/22/there-tabloidizationonline-news-content-analysis-traditional-news-websites/>. Last access: March $13^{\text {th }} 2016$.

MEYER, Philip. Os jornais podem desaparecer? Como salvar o jornalismo na era da informação. São Paulo: Contexto, 2007.

MOONEY, Attracta M. Tabloidization and the Irish press media: an analysis of how the Irish Independent reacted to the introduction of Irish versions of British tabloids. Thesis (Masters in Communication) - University of Leeds, 2008.

NINAN, Sevanti. Headlines from the Heartland: reinventing the Hindi public sphere. New Delhi (India): SAGE, 2012.

OGOLA, George; RODNY-GUMEDE, Ylva. The future of quality news 
journalism and media accountability in South Africa and Kenya. In ANDERSON; Peter, ; WILLIAMS, Michael. The future of quality news journalism. New York: Routledge, 2014, pp. 227-247.

PIONTEK, Dorota. The tabloidization of political discourse: the Polish case. Central European Journal of Communication, v. 2, pp. 275292, 2011.

RODRIGUES, Usha M. Print media in the era of globalization. In RANGANATHAN, Maya; Indian media in a globalized world. New Delhi (India): SAGE, 2010, pp. 52-68.

ROUDAKOVA, Natalia. Post-Soviet journalism as 'prostitution': Russia's reactions to Anna Politkovskaya's murder. Political Communication, v. 26, n. 4, pp. 412-429, 2009.

SANT'ANNA, Lourival. O destino do jornal: a Folha de S. Paulo, $\mathbf{O}$ Globo e $\mathbf{O}$ Estado de $\mathbf{S}$. Paulo na sociedade da informação. Rio de Janeiro: Record, 2008.

SCHUDSON, Michael. What does public journalism knows about journalism but doesn't know about 'public'? In: GLASSER, Theodore L. (Org.). The idea of public journalism. New York and London: The Guilford Press, 1999, pp. 118-133.

SOOD, Varun. Danik Jagran sees continued growth. Financial Times, August $30^{\text {th }}$ 2009. Available on: <http://www.ft.com>. Last access: January $1^{\text {st }} 2013$.

SPARKS, Colin. Introduction. In SPARKS, Colin. Javnost: the Public, "Tabloidization and the media", v. 5, n. 3, pp. 1-5, 1998.

SPARKS, Colin.; DALHGREN, Peter (Org.). Journalism and popular culture. California: SAGE, 1992.

SPARKS, Colin. Introduction: The panic over tabloid news. In:

TULLOCH, John. Tabloid tales. New York: Rowman \& Littlefield, 2000, pp. 1-40.

TULLOCH, John. The eternal recurrence of New Journalism. In: SPARKS, Colin; Tabloid tales. New York: Rowman \& Littlefield, 2000, pp. 131-146.

URIBE, Rodrigo; GUNTER, Barrie. Research note: The tabloidization of British tabloids. European Journal of Communication, 19, pp. 387402, 2004.

WASSERMAN, Herman. Tabloid journalism in South Africa: True story! Indianapolis: Indiana University Press, 2010. 


\section{NOTES}

1 This article is a reduced version of the working paper presented at the "Media, Politics and Elections" Workgroup at the National Association for Research and Graduate Studies in Social Sciences Conference (Anpocs), in 2014. We would like to thank to all colleagues from the group, specially Ricardo Fabrino Mendonça, Fernando LattmanWeltman and Kelly Prudêncio, among others. This version does not incorporate, for reasons of space, empirical data discussed at the occasion, using Brazilian Media Research (SECOM) database, about Brazilian print newspapers' market. For this final draft, we also thank the anonymous reviewers of the original manuscript submitted to this journal, that brought several new questions for the present work and future developments.

2 And, as a consequence, there's a little distance from our approach to those who emphasize the sensationalist language of popular journalism as its main feature (see BARBOSA \& ENNE, 2005).

3 According to Esser, the term was coined in the first half of $20^{\text {th }}$ Century and makes reference to a drug brand, that manufactured pills (or tablets). "This narcotic tabloid effect and the fact that it is easy to swallow have been readily transferred to the media" (ESSER, 1999, p. 292).

4 Continued research on this topic will also investigate the ideological-pamphleteer positioning of tabloids in relation to the media conglomerates that hold them.

5 The classifieds of $O$ Globo (The Globe) and Extra, two papers from the Infoglobo group, one quality and one middle-income/popular, were already unified, since May 2012.

Viktor Chagas is a professor at the Department of Media and Cultural Studies at Fluminense Federal University (UFF). PhD in History, Politics and Cultural Assets (Cpdoc-FGV). <viktor@midia.uff.br> 